\title{
SISTEM HIPONIMI HEWAN DALAM BAHASA JAWA: KAJIAN SEMANTIK
}

Hyponimy of Animals in Javanese Language: Semantics Perspective

\section{Endang Sri Maruti, Bambang Eko Hari Cahyono dan Wachidatul Linda Yuhanna Universitas PGRI Madiun}

Jalan Setia Budi Nomor 85, Kanigoro, Kec. Kartoharjo, Kota Madiun, Jawa Timur, Indonesia endang@unipma.ac.id

\begin{abstract}
Abstrak
Hewan-hewan di dunia sangat beragam dan tak terhitung banyaknya. Ragam hewan dalam bidang ilmu biologi dibagi ke dalam kingdom, spesies, famili, ordo, dan kelas. Penggolongan hewan dalam ilmu Biologi tentu berbeda dengan penggolongan hewan dalam masyarakat Jawa. Penelitian ini bertujuan untuk menjelaskan hiponimi hewan dalam bahasa Jawa berdasarkan kajian Semantik. Hiponim tidak terlepas dari relasi makna. Penelitian ini berpendekatan deskriptif kualitatif. Data dikumpulkan dengan dokumentasi, observasi, simak, dan catat. Penganalisisan data dilakukan dengan metode agih dengan teknik substitusi dan metode reflektifintrospektif dengan berdasarkan pada model alir yang di dalamnya terdapat reduksi, penyajian, verifikasi, dan inferensi. Spesies hewan beragam dan tak terhitung banyaknya. Dalam Semantik bahasa Jawa, kewan 'hewan' mempunyai kesamaan komponen dengan tetuwuhan 'tumbuhan'. Selanjutnya, sebagai subordinat, kewan memiliki komponen di antaranya rajakaya, sato iwen, omahan, dan alasan. Dalam kategori hewan pomahan atau ingon-ingon, terdiri atas tiga jenis, yakni rajakaya, sato iwen, dan kewan lulut. Pembedaan atas beberapa hiponim dilakukan dengan analisis komponen. Rajakaya 'hewan ternak' dapat dibedakan berdasarkan ukuran, tenaga, warna, dan aspek pemanfaatannya. Sato iwen dapat dibedakan berdasarkan ukuran, suara, bentuk paruh, bentuk kaki, dan pemanfaatan hewan, dan kewan lulut dibedakan berdasarkan ukuran, harga, tingkat kepatuhan, jenis makanan, dan jenis perawatan
\end{abstract}

Kata-kata kunci: hiponimi hewan, analisis similaritas, analisis komponen makna

\begin{abstract}
The animals in the world are very diverse and countless. The variety of animals in the field of biology is divided into kingdoms, species, families, orders, and classes. The classification of animals in biology is certainly different from the classification of animals in Javanese society. This study aims to explain animal hyponymy in Javanese based on Semantic studies. Hyponyms are inseparable from the relation of meaning. This research is descriptive qualitative. Data collection is done by documentation, observation, listening, and taking notes. Data analysis was carried out using the agih method with the substitution technique and the reflexive-introspective method based on the flow model in which there is reduction, presentation, verification, and inference. Animal species are diverse and innumerable. In Javanese semantics, kewan 'animal' has the same components as tetuwuhan 'plant'. Furthermore, as a subordinate, kewan has components in between rajakaya, sato iwen, omahan, and alasan. In the category of pomahan or ingon-ingon animals, there are three types, namely rajakaya, sato iwen, and kewan lulut. Differentiation of several hyponyms is done by component analysis. Rajakaya 'farm animals' can be distinguished based on size, power, color, and aspects of their use. Sato iwen can be distinguished based on size, sound, beak shape, leg shape, and animal utilization, and kewan lulut can be distinguished based on size, price, level of compliance, type of food, and type of care.
\end{abstract}

Keywords: hyponymy of animal, similarity analysis, meaning component analysis

How to Cite: Maruti, E., S., Cahyono, B., E., H., \& Yuhanna, W., L. (2021). Sistem Hipoimi dalam Bahasa Jawa: Kajian semantik. Ranah: Jurnal Kajian Bahasa. 10(2). 229-239. doi: https://doi.org/10.26499/rnh.v10i2.2243 


\section{PENDAHULUAN}

Hewan-hewan di dunia sangat beragam dan tak terhitung banyaknya. Keberagaman hewan itu dalam ilmu Biologi dapat dikategorikan dalam beberapa filum dan kelas dengan ciri-ciri setiap filum dan kelas. Secara umum, hewan dibedakan menjadi invertebrata dan vertebrata berdasarkan ada atau tidaknya tulang belakang. Klasifikasi intervebrata terdiri dari filum Porifera, Coelenterata, Plathyhelminthes, Nemathelminthes, Annelida, Mollusca, Arthopoda, dan Echinodermata (Yusriya et al., 2014). Sedangkan, Vertebrata terdiri atas kelas Pisces, Amfibi, Reptilia, Aves dan Mamalia (Yuhanna et al., 2021).

Berdasarkan pengelompokkan hewan dalam ilmu Biologi tersebut sudah sangat rinci dan jelas, namun bagi masyarakat Jawa, pengelompokkan hewan dalam bahasa Jawa masih sangat rumit dan juga tergolong unik. Dalam bahasa Jawa, nama hewan dikelompokkan berdasarkan sifat dan habitat. Berdasarkan sifat hewan dalam bahasa Jawa yang unik itulah, muncul penggolongan hewan yang unik pula. Bahkan, ada beberapa yang menyamakan antara kelompok hewan satu dengan kelompok hewan yang lainnya. Misalnya saja, menthog 'angsa' dan bebek. Banyak yang mengira kalau kedua jenis hewan itu sama (Yusuf, 2014). Dalam bahasa Jawa, jika dilihat dari kelas besarnya, pitik 'ayam', menthog 'angsa', bebek 'bebek', banyak dan basong termasuk dalam sato iwen 'hewan bersayap'. Namun sampai saat ini, belum ada penjelasan pembeda di antara keempat jenis hewan tersebut, sehingga banyak yang menganggap hewan-hewan itu sama.

Dalam kasus tersebut, hubungan makna yang demikian termasuk relasi makna dalam kajian ilmu semantik. Bahasa sebagai sebuah sistem memiliki komponen-komponen yang tersusun secara hierarkis. Komponen penyusun tersebut saling memberi arti, saling berhubungan, dan saling menentukan (Suhartatik \& Azis, 2019). Konsep inilah yang disebut dengan konsep hiponim dan hipernim. Konsep ini menggambarkan akan adanya kelas bawahan dan kelas atasan atau adanya makna sebuah kata yang berada di bawah makna kata lain. Sebuah kata yang merupakan hipernim terhadap sejumlah kata lain, akan menjadi hiponim terhadap kata lain yang hierarki berada di atasnya, mudah diterapkan pada kata benda. Dalam penelitian ini, konsep hiponim dan hipernim dikhususkan pada hewan.

Penelitian tentang hiponimi telah banyak dilakukan, namun belum ada penelitian tentang hiponimi dalam Bahasa Jawa khususnya pada hiponimi hewan. Sejauh ini, hiponimi telah banyak dilakukan dalam bahasa Indonesia. Sutarsih (2018) telah menganalisis hiponim dari kata mencuci. Sumarlam (2020) telah menemukan struktur hiponimi dalam bahasa yang digunakan oleh Joko Widodo. Selanjutnya, Mulyati (2010) telah menemukan penanda hubungan sinonimi dan hiponimi pada tajuk rencana dalam bahasa Indonesia. Pada teks tajuk rencana yang diteliti, telah menemukan beberapa penanda hubungan sinonimi dan hiponimi namun belum menyentuh pada analisis komponen makna. Hiponimi pada penamaan merk mobil telah dilakukan oleh Putra (2014).

Selain penelitian hiponimi dalam bahasa Indonesia di atas, penelitian hiponimi dalam bahasa Jepang sudah dilakukan oleh Amalijah (2014). Penelitian hiponimi dalam bahasa daerah juga pernah dilakukan sebelumnya, seperti hiponimi dalam bahasa Sunda yang dilakukan oleh Nurhapitudin \& Hamdani (2016). Adanya relasi makna antara kosakata bahasa Indonesia dan bahasa Sunda yang ditunjukkan dengan banyaknya sumber data kosakata berhiponimi dan polisemi. Hiponimi dalam bahasa Madura juga sudah pernah dilakukan (Abd Azis, 2019; Suhartatik \& Azis, 2019). Utami (2017) menyatakan bahwa relasi makna antarleksikal berkenaan dengan tanaman bambu dalam bahasa Bali dan penggunaan praksis sosial sebagai lingkungan bahasa terkait dengan keseimbangan hidup. Dari hasil penelitiannya ditemukan meronimi dan taksonomi hiponim bambu dalam bahasa Bali dan leksikon terkait 
terbentuk dari praksis sosial yang membangkitkan sifat ekologis manusia untuk upaya pelestarian.

Persamaan penelitian ini dengan penelitian terdahulu tersebut adalah sama-sama meneliti hiponimi. Adapun perbedaannya adalah penelitian tersebut meneliti hiponimi dalam bahasa Indonesia, Sunda, dan Bali, sedangkan penelitian ini meneliti hiponimi dalam bahasa Jawa. Perbedaan berikutnya adalah objek penelitian. Penelitian Utami (2017) mengenai kata yang berkenaan dengan tanaman bambu dalam bahasa Bali dan penelitian Nurhapitudin \& Fakri Hamdani (2016) mengenai kata dalam bahasa Indonesia dan bahasa Sunda yang merupakan polisemi sekaligus homonimi, sedangkan penelitian ini berfokus kepada penelitian hiponimi pada hewan dalam bahasa Jawa.

Bertolak dari latar belakang tersebut, rumusan masalah dalam penelitian ini adalah sebagai berikut: (1) bagaimana kelas kata yang merupakan anggota hiponim hewan dalam bahasa Jawa; dan (2) bagaimana perbedaan kata yang merupakan anggota hiponim hewan dalam bahasa Jawa. Oleh karena itu, tujuan penelitian ini adalah untuk: (1) menemukan kelas kata yang merupakan anggota hiponim hewan dalam bahasa Jawa; dan (2) menemukan perbedaan kata yang merupakan anggota hiponim hewan dalam bahasa Jawa.

\section{LANDASAN TEORI}

Dalam kamus linguistik, hiponimi merupakan hubungan antara makna spesifik dan makna generik, atau antara anggota taksonomi dan nama taksonomi dalam ilmu semantik (Kridalaksana, 2008:83). Istilah yang dipakai Leech (1976) untuk menyebut hiponimi adalah memasukkan (inclusion) makna (Umagandhi \& Vinothini, 2017), yakni dengan melihat komponen penyusun yang terdapat di antara dua makna, jika salah satu makna yang rumus komponennya mengandung semua ciri yang terdapat di dalam rumus makna yang lain, itulah yang disebut hiponimi. Pendapat ini sejalan dengan Hurford et al. (2007) yang menyatakan bahwa hiponim merupakan makna kata yang dimasukkan atau disyaratkan menjadi kata yang lebih umum. Makna spesifik merupakan hiponim dari makna generik (Mamatov \& Mirzaakbarov, 2019). Jadi, dalam hiponimi ada keterpayungan makna, makna sebuah kata termasuk ke dalam makna kata yang lain.

Dalam ilmu kebahasaan suatu kata dengan banyak variasi yang merujuk ke suatu kata dan memiliki hubungan makna dengan kata tersebut dikenal sebagai hiponim (Sutarsih, 2018). Jadi, kata yang masuk ke dalam sebuah hiponim memiliki variasi bentuk, tetapi maknanya berhubungan. Hubungan tersebut terlihat dari komponen makna yang terkandung dalam kata yang merupakan hiponim. Makna kata yang merupakan hiponim tersebut ada yang denotatif dan ada pula yang konotatif. Kata tersebut ada yang maknanya merupakan kata yang mencakupi kata lainnya dan ada kata-kata yang merupakan cakupan dari kata lainnya. Dengan demikian, makna suatu kata dapat merupakan bagian dari makna kata lainnya atau makna suatu kata mencakupi makna kata lainnya.

Kata hiponimi awalnya berasal dari bahasa Yunani Kuno, yakni berasal dari kata onoma yang berarti 'nama' dan kata hypo yang berarti 'di bawah'. Jadi secara harfiah, hiponimi merupakan 'nama yang termasuk dalam nama lain'. Secara semantik, Verhaar (2004) menyatakan hiponim adalah ungkapan (biasanya berupa kata, tetapi kiranya dapat juga frase atau kalimat) yang maknanya dianggap merupakan bagian dari makna suatu ungkapan lain. Hubungan atau relasi makna yang terdapat pada sinonim, antonim, dan homonim merupakan hubungan yang bersifat dua arah, sedangkan hubungan atau relasi makna yang terdapat pada hiponim merupakan hubungan yang bersifat satu arah (Lyons \& John, 1995).

Makna suatu kata bersifat ambigu (Ullmann, 2007). Untuk mengatasi keambiguan tersebut diberikan solusi berupa menganalisis komponen makna yang terkandung dalam setiap kata (Lyons, 2020). Dengan mengetahui komponen yang terkandung dalam suatu kata, 
dapat dilakukan pengelompokan kata berdasarkan persamaan komponen makna pembentuknya. Jadi, hubungan suatu kata terlihat dari komponen makna yang terkandung dalam kata tersebut. Makna beberapa kata yang tidak sama dapat menyatakan hubungan makna yang lebih dekat daripada makna beberapa kata yang sama (Cruse, 2002).

\section{METODE PENELITIAN}

Penelitian ini berjenis penelitian studi pustaka (library research) yang didukung dengan hasil penggunaan data di lapangan, sehingga penelitian ini menggunakan metode penelitian kualitatif deskriptif. Data berupa kata, frasa, dan kalimat yang dikumpulkan dari buku-buku teks berbahasa Jawa seperti majalah dan buku ajar di sekolah yang mengandung hiponimi hewan yang didukung dengan penggunaannya secara langsung di lapangan oleh masyarakat Jawa khususnya yang berada di Kota Madiun dan sekitarnya. Data yang terkumpul kemudian dianalisis dengan menggunakan beberapa langkah sesuai teori Miles \& Huberman (1994) yaitu menganalisis data dengan tiga langkah: kondensasi data (data condensation), menyajikan data (data display), dan menarik simpulan atau verifikasi (conclusion drawing and verification).

Analisis data menggunakan analisis komponen makna. Analisis komponen makna berangkat dari asumsi bahwa satuan leksikal menyatakan seperangkat atau kesatuan makna yang bersistem atau mengandung konfigurasi makna yang dapat diuraikan sampai pada komponen terkecilnya (Leech, 1976). Jadi, menganalisis suatu makna berarti menguraikan makna itu sampai kepada ciri pembedaya yang terkecil, yaitu komponen yang kontras sampai dengan komponen yang lain. Prosedur analisis komponen pembeda yang dilakukan adalah sebagai berikut. Pertama, menyeleksi serangkaian makna yang berkolokasi yang diperkirakan membentuk satu wilayah makna. Kedua, mendefinisikan makna kata-kata itu. Definisi ini bersifat sangat khas berdasarkan komponen diagnostik (komponen pembeda) suatu satuan makna. Terakhir, mengidentifikasikan komponen umum yang dimiliki bersama dan komponen diagnostik atau komponen pembedanya.

\section{PEMBAHASAN}

\section{Kedudukan Hewan dalam Satuan Barang}

Kata kewan merupakan bahasa Jawa yang berarti hewan. Kata hewan merupakan pinjaman dari bahasa Arab haiwan yang berarti binatang, kata binatang sendiri merupakan bahasa Melayu. Dalam bahasa Sanskerta, hewan sama dengan satwa yang berarti makhluk. Dalam bahasa Inggris, hewan disebut dengan animal, yang berasal dari bahasa Latin animalis yang berarti memiliki napas (Suhandono, 2000). Kewan atau hewan, binatang, satwa, atau fauna adalah organisme eukariotik multiseluler yang membentuk kerajaan Animalia dalam ilmu Biologi. Studi tentang hewan disebut zoologi. Adapun hubungan antara kewan 'hewan' dengan makhluk hidup ataupun makhluk mati berada dalam satu lingkup barang dapat dilihat dalam gambar di bawah ini. 


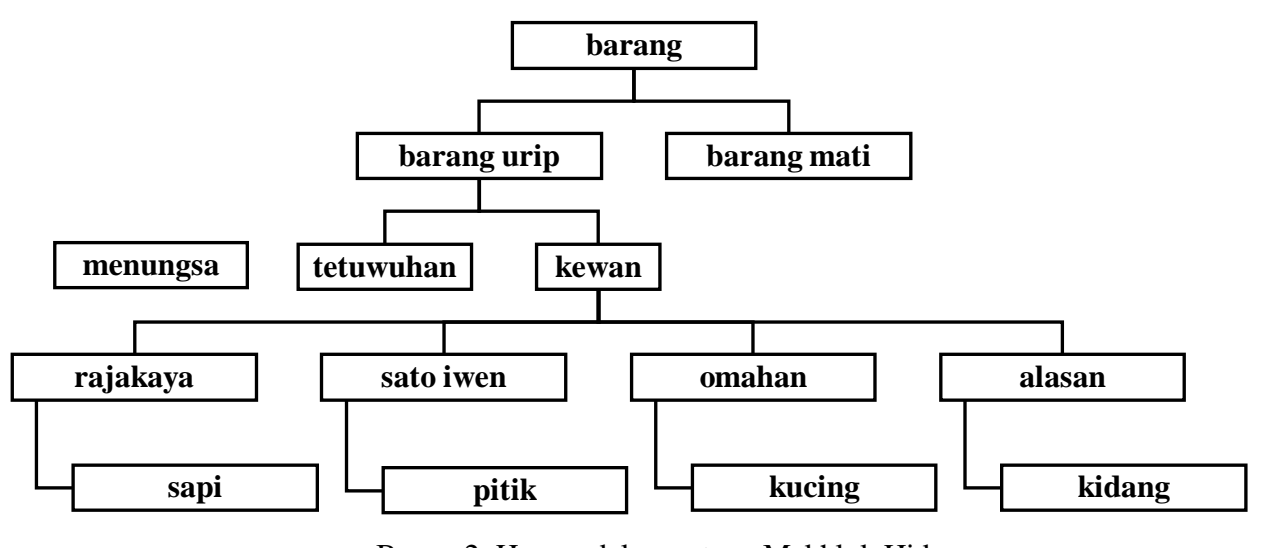

Bagan 2. Hewan dalam satuan Makhluk Hidup

Berdasarkan bagan di atas, kewan sebagai subordinat dari barang urip. Dalam semantik, kewan 'hewan' mempunyai kesamaan komponen dengan tetuwuhan 'tumbuhan'. Selanjutnya, sebagai subordinat, kewan memiliki komponen di antaranya rajakaya, sato iwen, omahan, dan alasan.

\section{Sistem Hiponim Hewan dalam Bahasa Jawa}

Pada masyarakat Jawa, hewan dibagi menjadi dua kelompok besar, yakni kewan pomahan lan kewan alasan (Suhandono, 2000). Masing-masing kelompok masih dibagi lagi berdasarkan kelompoknya. Dalam penelitian ini, pembahasan tentang hiponim pada hewan hanya dibatasi pada jenis hewan pomahan saja, yakni rajakaya, sato iwen, dan lulut. Adapun gambaran penggolongan hewan dalam bahasa Jawa secara umum adalah sebagai berikut.

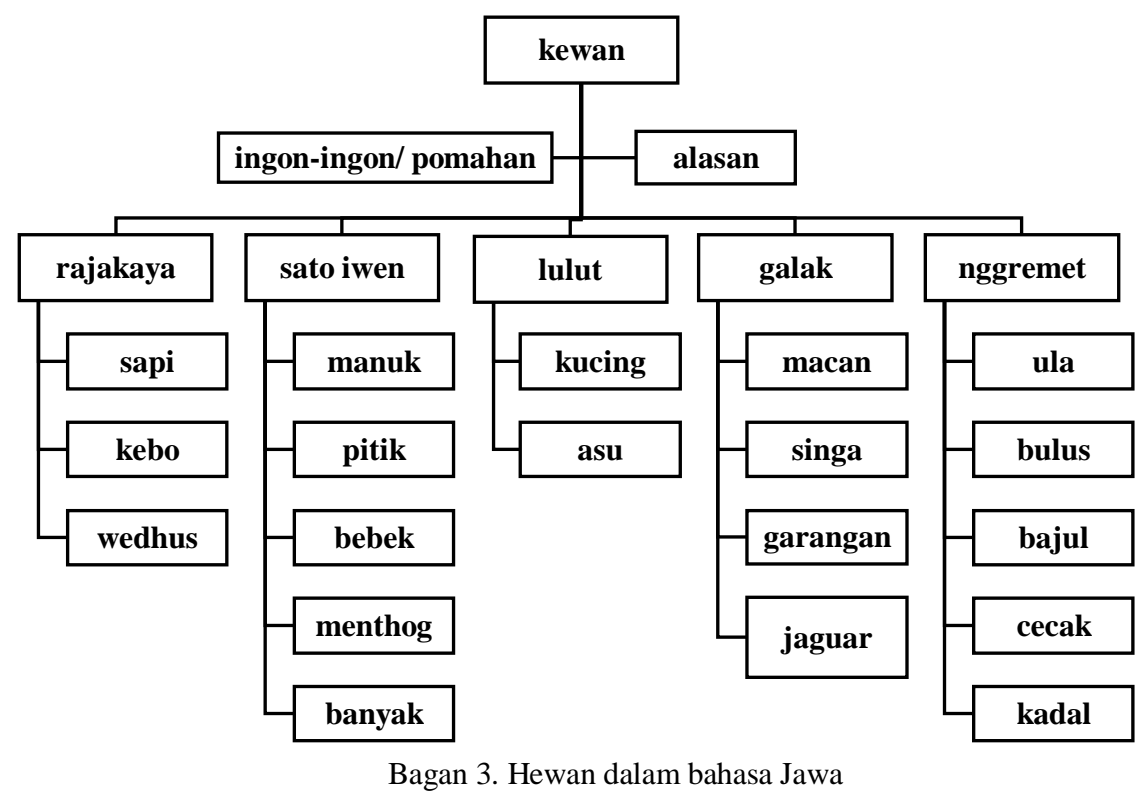

Kategori yang dibahas di sini adalah kewan ingon-ingon atau pomahan, yaitu hewan yang dipelihara dan hidup di sekitar rumah manusia. Dalam kategori hewan pomahan atau ingon-ingon, terdiri atas tiga jenis, yakni rajakaya, sato iwen, dan lulut. Materi ini yang sering diajarkan pada siswa sekolah dasar, namun materi yang diajarkan hanya sebatas pada tataran hafalan semata. Hal ini berbeda dengan hasil penelitian Kurniawati \& Karsana (2020) yang menyatakan bahwa penguasaan kosakata pada siswa dasar sudah tergolong baik. Penguasaan 
kosakata terutama nomina dalam bahasa Jawa khususnya terkait dengan hewan masih sangat minim.

\section{a. Rajakaya}

Rajakaya adalah hewan yang dipelihara sebagai bentuk simpanan harta, jika hewan itu dijual maka si empunya hewan itu seolah-olah menjadi sangat kaya seperti raja walaupun hanya sekejap saja. Rajakaya merupakan hipernim dari sapi, kebo, dan wedhus, sehingga sapi, kebo, dan wedhus merupakan hiponim dari rajakaya. Hubungan antara sapi, kebo, dan wedhus adalah sebagai kohiponim. Masing-masing hiponim ini juga masih memiliki kelas bawah, sehingga hiponim ini bisa menjadi hipernim. Misalnya sapi, ada sapi brahman, sapi pohan, dan sapi Australia. Begitu juga pada kebo dan wedhus. Hubungan ini sesuai dengan yang dipaparkan Nurhapitudin \& Hamdani (2016), bahwa untuk hipernim biasanya tidak diucapkan. Jadi jika ada yang mengatakan sapi, mitra tutur sudah paham jika sapi itu termasuk dalam rajakaya, sehingga tidak perlu mengucapkan rajakaya sapi. Namun, untuk menyebut hiponim dari sapi, masih banyak orang yang mengucapkan sapi brahman dan tidak hanya brahman saja. Hal itu tergambar dalam bagan di bawah ini.

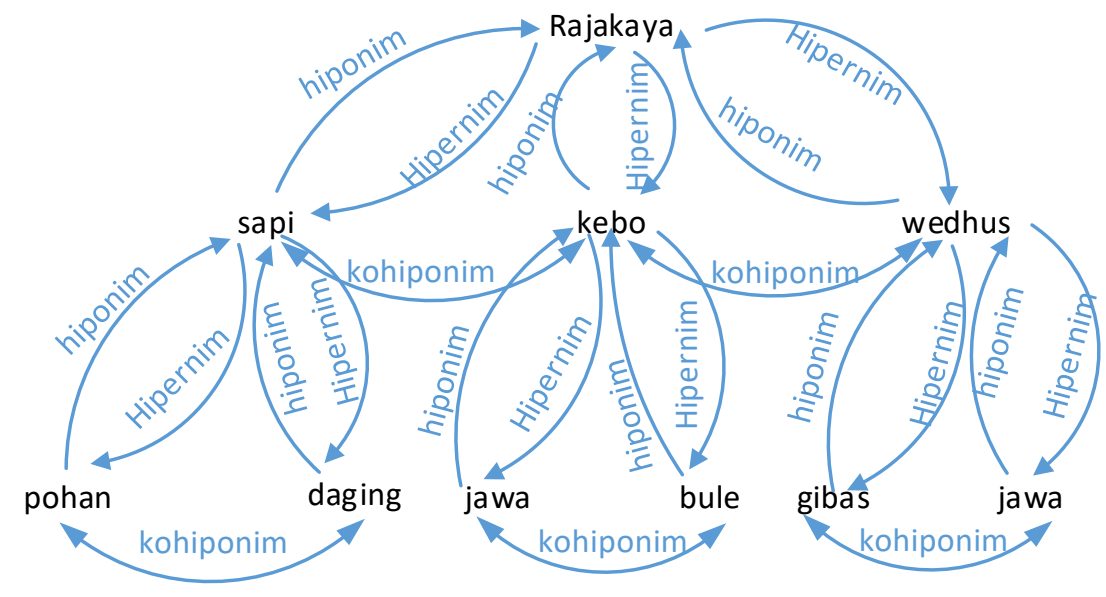

Bagan 4. Struktur Rajakaya dalam bahasa Jawa

Hubungan kohiponim ini bisa dianalisis perbedaannya berdasarkan komponen pembeda, Berikut ini analisis komponen makna yang mempunyai hubungan hiponim hewan rajakaya dalam bahasa Jawa.

Tabel 1.

Analisis Komponen Makna Hiponim Rajakaya dalam bahasa Jawa

\begin{tabular}{|c|c|c|c|c|c|c|}
\hline \multirow{2}{*}{$\begin{array}{c}\text { Komponen } \\
\text { pembeda }\end{array}$} & \multicolumn{2}{|c|}{ sapi } & \multicolumn{2}{|c|}{ kebo } & \multicolumn{2}{|c|}{$\begin{array}{l}\text { wedhus } \\
\end{array}$} \\
\hline & pohan & potong & jawa & bule & gimbas & jawa \\
\hline ukuran & + & + & + & + & - & - \\
\hline tenaga & + & + & + & + & - & - \\
\hline warna & - & + & + & - & + & - \\
\hline daging & - & + & + & + & + & + \\
\hline susu & + & - & - & - & - & - \\
\hline kulit & + & + & + & - & + & + \\
\hline
\end{tabular}

Keterangan: tanda + : mempunyai komponen makna

tanda - : tidak mempunyai komponen makna

Berdasarkan tabel di atas, rajakaya 'hewan ternak' mempunyai hiponim 3 kata, yakni sapi, kebo, dan wedhus. Sapi, kebo, dan wedhus mempunyai komponen makna hewan peliharaan. Kata sapi, kebo, dan wedhus merupakan hiponim dari rajakaya 'hewan ternak', yaitu hewan peliharaan, berkaki empat, berukuran besar, dan diternak untuk dapat diambil manfaatnya (daging, susu, kulit, dan tenaga). Untuk membedakan antara hiponim tersebut, bisa dilihat berdasarkan beberapa komponen. Pertama, dari segi ukuran, sapi dan kerbau lebih 
besar daripada wedhus. Berdasarkan komponen tenaga, jarang wedhus itu diambil tenaganya karena ukurannya yang relatif kecil. Dari segi warna, sapi bisa bermacam-macam warnanya, ada putih, hitam, dan cokelat; kebo berwarna hitam dan putih, sedangkan wedhus berwarna putih dan cokelat. Dalam pemanfaatannya, ketiganya bisa dimanfaatkan baik daging, susu, maupun kulitnya. Walaupun pada masyarakat awam, yang dapat menghasilkan susu hanya sapi, sedangkan susu kerbau dan susu kambing jarang ditemui. Menurut Bankova et al., (2018), hubungan perbedaan komponen makna seperti pada tabel tersebut merupakan hiponim gradual positif negatif.

\section{b. Sato Iwen}

Sato iwen adalah kumpulan hewan yang memiliki sayap dan dipelihara manusia untuk dimanfaatkan baik suara, daging, telur, maupun bulunya. Yang termasuk dalam adalah pitik, bebek, dan manuk. Manuk masih mempunyai kelas bawah lagi, yaitu manuk ocehan dan manuk anggungan. Manuk ocehan terdiri atas kenari, murai, labet, cucak ijo, dan lain sebagainya. Sedangkan, manuk anggungan terdiri atas puter, pugeru, derkuku, dan sebagainya. Begitu pula pada kelompok pitik, masih banyak lagi macamnya.

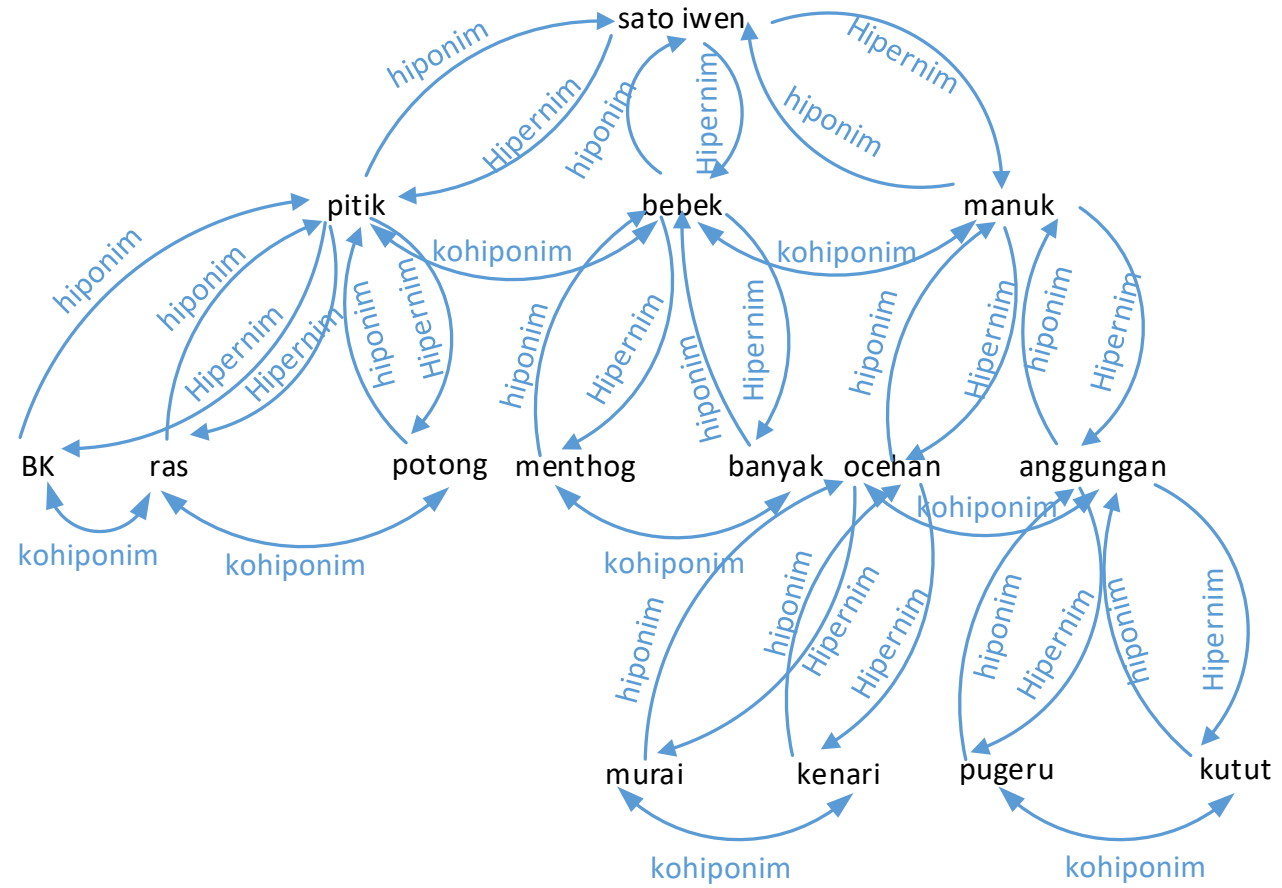

Bagan 5. Struktur Sato iwen dalam bahasa Jawa

Berdasarkan bagan di atas, sato iwen merupakan hipernim dari pitik, bebek, dan manuk, sehingga pitik, bebek, dan manuk merupakan hiponim dari sato iwen. Hubungan antara pitik, bebek, dan manuk adalah sebagai kohiponim. Masing-masing hiponim ini juga masih memiliki kelas bawah, sehingga hiponim ini bisa menjadi hipernim. Pitik menjadi hipernim dari hiponim BK, ras, dan potong. BK, ras, dan potong merupakan kohiponim. Bebek menjadi hipernim dari hiponim menthog dan banyak. Menthog dan banyak merupakan kohiponim. Manuk menjadi hipernim dari hiponim ocehan dan anggungan. Ocehan dan anggungan merupakan kohiponim. Ocehan dan anggungan yang menjadi hiponim dari manuk juga menjadi hipernim. Ocehan menjadi hipernim dari hiponim murai dan kenari. Murai dan kenari merupakan kohiponim. Anggungan pun bisa menjadi hipernim dari hiponim pugeru dan kutut. Pugeru dan kutut merupakan kohiponim. 
Dalam pengucapan maupun penulisan, hiponim dari semua sato iwen di atas tidak perlu diucapkan dan ditulis. Orang hanya mengucapkan BK saja sudah paham jika itu adalah termasuk dalam jenis sato iwen dari pitik. Begitupula pada hiponim bebek dan manuk. Jarang ada orang mengucapkan manuk kenari dan hanya perlu mengucapkan kenari, karena sudah pasti kenari itu merupakan jenis dari manuk.

Berdasarkan hubungan di atas, menurut Mamatov \& Mirzaakbarov (2019) masingmasing kohiponim dapat dicari perbedaannya dengan analisis komponen makna. Berikut ini analisis komponen makna yang mempunyai hubungan hiponim hewan sato iwen dalam bahasa Jawa.

Tabel 2.

Analisis Komponen Makna Hiponim Sato Iwen dalam bahasa Jawa

\begin{tabular}{lccccccc}
\multicolumn{7}{c}{ Komponen } & \multicolumn{7}{c}{ Analisis Komponen Makna Hiponim Sato Iwen dalam bahasa Jawa } \\
\cline { 2 - 8 } pembeda & BK & ras & potong & menthog & banyak & ocehan & anggungan \\
\hline ukuran & + & + & + & - & + & - & + \\
suara & + & - & - & - & + & + & + \\
paruh & - & - & - & - & + & - & - \\
kaki & + & + & + & - & + & - & - \\
daging & - & - & + & + & + & - & - \\
telur & - & + & - & + & + & - & - \\
bulu & + & + & + & + & + & - & + \\
\hline
\end{tabular}

Berdasarkan tabel di atas, sato iwen 'hewan unggas' mempunyai hiponim 3 buah, yakni pitik, bebek, dan manuk. Pitik, bebek, dan manuk mempunyai komponen makna hewan peliharaan. Kata pitik, bebek, dan manuk merupakan hiponim dari sato iwen 'hewan unggas', yaitu hewan peliharaan, berkaki dua, berukuran kecil, dan diternak untuk dapat diambil manfaatnya (daging, telur, bulu, dan suara). Untuk membedakan antara hiponim tersebut, bisa dilihat berdasarkan beberapa komponen. Pertama, dari segi ukuran, pitik dan bebek lebih besar daripada manuk. Berdasarkan komponen suara, manuk lebih banyak berpotensi. Berdasarkan bentuk paruhnya, bebek memiliki paruh yang relatif lebih besar dan tidak runcing, berbeda dengan pitik dan manuk yang berparuh kecil dan tajam. Dari bentuk kaki, manuk tidak memiliki selaput kaki, berbeda dengan pitik dan bebek yang berselaput kaki lebih lebar dan biasanya digunakan untuk berenang. Dari segi pemanfaatan daging dan telur, manuk tidak ada potensi untuk dimanfaatkan daging dan telur, walaupun ada jenis telur puyuh.

\section{c. Hiponim Kewan Lulut}

Kelompok hewan pomahan selanjutnya adalah kelompok hewan lulut, yaitu hewan yang dipelihara manusia karena hewan ini dianggap tidak berbahaya dan justru bisa menjadi teman si empunya. Hewan ini berbeda dengan sato iwen yang dipelihara untuk diambil manfaat dari bagian tubuhnya, hewan lulut dipelihara karena bisa dijadikan teman atau bisa juga sebagai penjaga rumah. Kucing dan asu 'anjing' termasuk dalam kelompok hewan lulut. Kucing sendiri masih banyak lagi jenisnya, ada kucing anggora, persia, dan masih banyak lagi. Begitu pula pada jenis asu 'anjing'. 


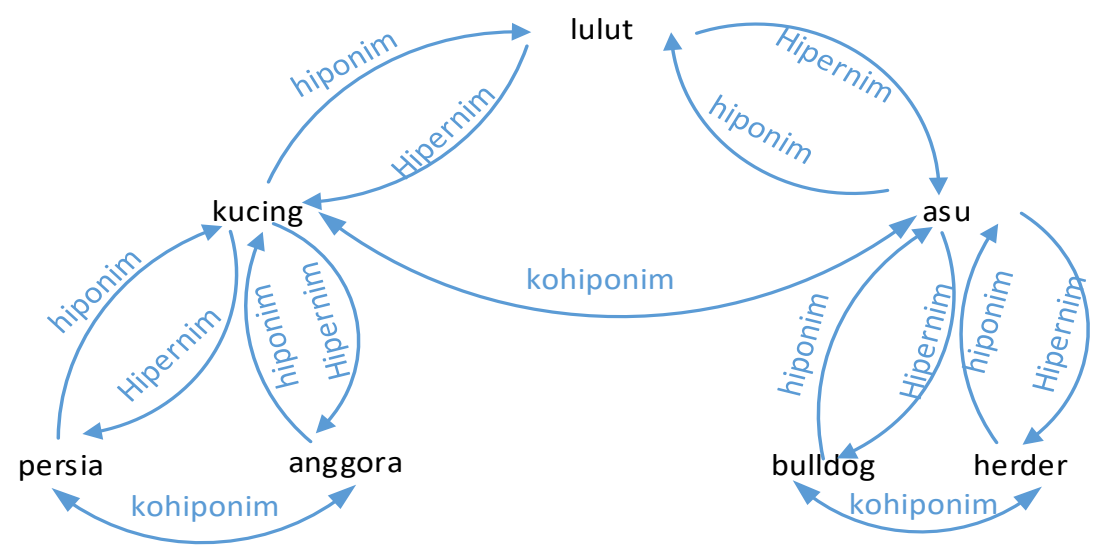

Bagan 6. Struktur Kewan Lulut dalam bahasa Jawa

Berdasarkan bagan di atas, kewan lulut merupakan hipernim dari kucing dan asu, sehingga kucing dan asu merupakan hiponim dari kewan lulut. Hubungan antara kucing dan asu adalah sebagai kohiponim. Masing-masing hiponim ini juga masih memiliki kelas bawah, sehingga hiponim ini bisa menjadi hipernim. Kucing menjadi hipernim dari hiponim anggora, persia, dan Jawa. Anggora, persia, dan Jawa merupakan kohiponim. Asu menjadi hipernim dari hiponim bulldog dan herder. Bulldog dan herder merupakan kohiponim.

Berdasarkan hubungan di atas, masing-masing kohiponim dapat dicari perbedaannya dengan analisis komponen makna. Berikut ini analisis komponen makna yang mempunyai hubungan hiponim kewan lulut dalam bahasa Jawa.

Tabel 3.

Analisis Komponen Makna Hiponim Hewan Lulut dalam bahasa Jawa

\begin{tabular}{lccccc}
\hline \multicolumn{2}{c}{ Komponen pembeda } & \multicolumn{5}{c}{ kucing } & \multicolumn{3}{c}{ asu } \\
\cline { 2 - 6 } & persia & anggora & Jawa & bulldog & herder \\
\hline ukuran & + & + & - & + & + \\
harga & + & + & - & + & + \\
patuh & + & + & - & - & - \\
bulu & + & + & - & + & + \\
makanan & + & + & - & + & + \\
rantai & - & - & - & + & + \\
perawatan & + & + & - & + & + \\
\hline
\end{tabular}

Berdasarkan tabel di atas, kewan lulut 'hewan teman manusia' mempunyai hiponim 2 buah, yakni kucing dan asu. Kucing dan asu mempunyai komponen makna hewan peliharaan sebagai teman manusia. Kata kucing dan asu merupakan hiponim dari kewan lulut 'hewan teman manusia', yaitu hewan peliharaan, berkaki empat, berbulu, lucu, bisa dilatih untuk patuh, berukuran kecil, dan dipelihara untuk dapat dijadikan teman. Untuk membedakan antara hiponim tersebut, bisa dilihat berdasarkan beberapa komponen. Pertama, dari segi ukuran, anjing lebih besar daripada kucing. Berdasarkan kisaran harga, kucing dan asu blesteran lebih mahal daripada kucing Jawa atau kucing liar. Tingkat kepatuhan keduanya sama bergantung pada pelatihan dan pembiasaan. Keduanya sama-sama berbulu, namun bulu kucing lebih lembut daripada bulu anjing. Berdasarkan makanannya, makanan kucing lebih mudah daripada anjing, dan juga lebih terjangkau. Walaupun sama-sama patuh, namun anjing selalu diberi rantai pada lehernya, namun kucing tidak selalu ada. Perawatan keduanya sama, bergantung pada jenis kucing dan anjingnya. 
Berdasarkan analisis perbedaan tersebut sudah dapat didefinisikan masing-masing hiponim dari hewan lulut. Jika diajarkan pada siswa sekolah, hal tersebut dapat ditanyakan oleh guru: hewan peliharaan apa yang selalu memakai rantai di lehernya? Dengan analisis komponen seperti di atas, siswa tidak lagi bingung untuk membedakan jenis-jenis hewan peliharaan. Hal itu sesuai dengan Bankova et al., (2018), yang memberikan contoh clowy kuwi asu dan clowy kuwi kewan. Dengan demikian, hiponim dari masing-masing hipernim yang hipernim itu juga merupakan hiponim dari hipernim di atasnya, memiliki komponen makna yang sama.

Keseluruhan analisis data tentang hewan peliharaan di atas dapat ditarik benang merah jika selama ini hewan peliharaan itu mencakup semua hewan yang dipelihara manusia di rumah. Namun belum ada perbedaan yang jelas antara jenis hewan peliharaan itu.

Tabel 4.

Objek Analisis Hiponim Hewan dalam bahasa Jawa

\begin{tabular}{|c|c|c|c|c|c|c|}
\hline \multirow{2}{*}{ Kata } & \multicolumn{4}{|c|}{ Objek analisis } & \multirow{2}{*}{$\begin{array}{c}\text { Simpulan } \\
\text { rumusan }\end{array}$} & \multirow{2}{*}{$\begin{array}{l}\text { Kategor } \\
\text { semantil }\end{array}$} \\
\hline & simbol & konteks & imagi & referen & & \\
\hline $\begin{array}{l}\text { clowy kuwi } \\
\text { asu }\end{array}$ & asu & $\begin{array}{l}\text { Hewan } \\
\text { peliharaan }\end{array}$ & $\begin{array}{l}\text { Hewan } \\
\text { peliharaan yang } \\
\text { bisa dijadikan } \\
\text { teman }\end{array}$ & jinak & $\mathrm{s} 1 \sim \mathrm{i} 1 \sim \mathrm{r} 1$ & Hiponim \\
\hline $\begin{array}{l}\text { clowy kuwi } \\
\text { kewan }\end{array}$ & kewan & hewan & $\begin{array}{l}\text { Jenis makhluk } \\
\text { hidup yang } \\
\text { bernafas, } \\
\text { multiseluler } \\
\text { yang } \\
\text { membentuk } \\
\text { kerajaan } \\
\text { Animalia }\end{array}$ & liar & $\mathrm{s} 2 \sim \mathrm{i} 2 \sim \mathrm{r} 1$ & Hipernim \\
\hline
\end{tabular}

Berdasarkan tabel di atas, hiponimi merupakan hubungan dua arah dengan 2 bagan seperti berikut
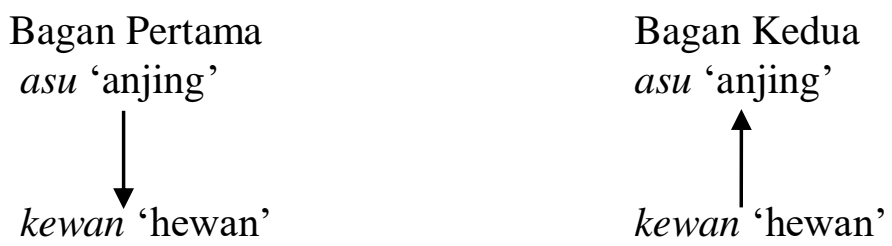

Bagan 1 menunjukkan bahwa asu 'anjing' merupakan hiponim dari kewan 'hewan', dan bagan 2 menggambarkan bahwa kewan 'hewan' merupakan hipernim (superordinat) dari asu 'anjing'.

\section{PENUTUP}

Berdasarkan uraian di atas dapat disimpulkan bahwa kewan 'hewan', binatang, satwa, atau fauna adalah organisme eukariotik multiseluler yang membentuk kerajaan Animalia dalam ilmu Biologi. Dalam Semantik bahasa Jawa, kewan 'hewan' mempunyai kesamaan komponen dengan tetuwuhan 'tumbuhan'. Selanjutnya, sebagai subordinat, kewan memiliki komponen di antaranya rajakaya, sato iwen, omahan, dan alasan. Dalam katagori hewan pomahan atau ingon-ingon, terdiri atas tiga jenis, yakni rajakaya, sato iwen, dan lulut.

Hubungan hiponim dalam hewan bersifat dua arah. Masing-masing hipernim yang juga merupakan hiponim dari hipernim di atasnya, memiliki komponen makna yang sama. Dengan mengetahui komponen yang terkandung dalam suatu kata, dapat dilakukan pengelompokan kata berdasarkan persamaan komponen makna pembentuknya. Jadi, hubungan suatu kata terlihat dari komponen makna yang terkandung dalam kata tersebut. Berdasarkan hasil analisis komponen, rajakaya 'hewan ternak' dapat dibedakan berdasarkan ukuran, tenaga, 
warna, dan aspek pemanfaatannya. Selanjutnya, sato iwen dapat dibedakan berdasarkan ukuran, suara, bentuk paruh, bentuk kaki, dan pemanfaatan hewan. Terakhir, kewan lulut dapat dibedakan berdasarkan ukuran, harga, tingkat kepatuhan, jenis makanan, dan jenis perawatan. Hiponim memiliki pola hubungan transitif. Misalnya, A itu hiponim dari B, dan B itu sendiri merupakan hiponim dari C, maka sudah pasti jika A itu hiponim dari C.

\section{DAFTAR PUSTAKA}

Amalijah, E. (2014). Hubungan antara Hiponim dengan Entailment dalam Bahasa Jepang. PARAFRASE: Jurnal Kajian Kebahasaan \& Kesastraan, 14(01).

Bankova, D., Coecke, B., Lewis, M., \& Marsden, D. (2018). Graded Hyponymy for Compositional Distributional Semantics. Journal of Language Modelling, 6(2), 225-260. https://doi.org/10.15398/jlm.v6i2.230

Cruse, D. A. (2002). Hyponymy and its Varieties. In The semantics of relationships (pp. 3-21). Springer. https://doi.org/10.1007/978-94-017-0073-3_1

Hurford, J. R., Heasley, B., \& Smith, M. B. (2007). Semantics: a coursebook. Cambridge university press. https://doi.org/10.1017/CBO9780511841668

Kurniawati, W., \& Karsana, D. (2020). Aspek Penguasaan Kosakata Bahasa Indonesia oleh Siswa Sekolah Dasar di Kota Medan. Ranah: Jurnal Kajian Bahasa, 9(2), 286. https://doi.org/10.26499/rnh.v9i2.2977

Leech, G. (1976). Semantics. Philosophy and Rhetoric, 9(1).

Lyons, J. (2020). Structural semantics. http://hdl.handle.net/10955/2309

Lyons, J., \& John, L. (1995). Linguistic Semantics: an Introduction. Cambridge University Press. https://doi.org/10.1017/CBO9780511810213

Mamatov, A., \& Mirzaakbarov, S. (2019). Uzbek Comperative Analysis of Hyponymy in English Graduonymic Phrasemes. Mental Enlightenment Scientific-Methodological Journal, 2019(1), 14.

Miles, M. B., \& Huberman, A. M. (1994). Qualitative Data Analysis: an Expanded Sourcebook. SAGE.

Mulyati, R. (2010). Penanda Hubungan Sinonimi dan Hiponimi pada Tajuk rencana Harian Solopos Edisi November-Desember 2009. Universitas Muhammadiyah Surakarta.

Nurhapitudin, I., \& Hamdani, F. (2016). Hiponimi dan Polisemi Bahasa Indonesia dan Bahasa Sunda. AlTsaqafa: Jurnal Ilmiah Peradaban Islam, 13(2), 353-336. https://doi.org/10.15575/altsaqafa.v13i02.1982

Putra, B. P. (2014). Hiponimi dan Penamaan BMW dan Mercedes-Benz dalam Majalah Auto Bild Indonesia: Kajian Semantik Leksikal. Bandung: Tesis Magister Universitas Padjajaran

Suhandono. (2000). Klasifikasi Folk Biologi dalam Bahasa Jawa Sebuah Pengamatan Awal. Humaniora, 2 (12) .

Suhartatik, S., \& Azis, A. (2019). Studi Relasi Makna Nomina Bahasa Madura di Kabupaten Sumenep. Konferensi Nasional Bahasa dan Sastra V, 5(1), 268-273. https://doi.org/10.36379/estetika.vli1.1

Suhartatik, S., \& Azis, A. (2019). Hubungan Ketercakupan Kemaknaan Adjektiva Bahasa Madura di Kabupaten Sumenep. Jurnal Pendidikan, 2(2), 16-19. https://www.jurnal.iainkediri.ac.id/index.php/happiness/article/view/1891

Sumarlam, S. (2020). Penggunaan Hiponimi pada Caption Postingan Akun Instagram Resmi Presiden Joko Widodo. Jurnal Ilmiah Telaah, 5(2), 8-17.

Sutarsih. (2018). Hiponimi Kata Mencuci dalam Bahasa Indonesia. Jala Bahasa: Jurnal Ilmiah Kebahasaan, 14(1), 91-114. https://doi.org/10.36567/jalabahasa.v14i1.184

Ullmann, S. (2007). Pengantar Semantik terj. Sumarsono. Yogyakarta: Pustaka Pelajar.

Umagandhi, R., \& Vinothini, M. (2017). Leech's Seven Types of Meaning in Semantics. International Journal of Multidisciplinary Research and Development, 4(3).

Utami, G. W. N. (2017). Relasi Makna Leksikon Tiing dalam Bahasa Bali Berbasis Lingkungan. LITERA: Jurnal Litera Bahasa dan Sastra, 3(1). https://doi.org/10.21009/AKSIS.010203

Verhaar, J. W. M. (2004). Asas-Asas Linguistik Umum [The Principles of General Linguistics]. Yogyakarta: UGM Press.

Yuhanna, W. L., Al Muhdhar, M. H. I., Gofur, A., \& Hassan, Z. (2021). Self-reflection assessment in vertebrate zoology (Sravz) using rasch analysis. Jurnal Pendidikan IPA Indonesia, 10(1), 35-47. https://doi.org/10.15294/jpii.v10i1.25603

Yusriya, A., Santosa, K., \& Priyono, B. (2014). Pengembangan Video Pembelajaran Materi Klasifikasi Hewan sebagai Suplemen Bahan Ajar Biologi SMP. Journal of Biology Education, 3(1). 